\title{
UNIVERSITYOF
}

FORWARD

THINKING

WESTMINSTER用

WestminsterResearch

http://www.westminster.ac.uk/westminsterresearch

Sexual Knowledge and the Formation of Chinese Modernity

Kehoe, S.

This is a copy of the author manuscript of a book review published in GLQ: A Journal of Lesbian and Gay Studies, 27 (1), p. 155-157. The final definitive version is available from the publisher at:

https://doi.org/10.1215/10642684-8776960

(C) 2021 by Duke University Press

The WestminsterResearch online digital archive at the University of Westminster aims to make the research output of the University available to a wider audience. Copyright and Moral Rights remain with the authors and/or copyright owners. 


\section{Sexual Knowledge and the Formation of Chinese Modernity}

\section{Séagh Kehoe}

After Eunuchs: Science, Medicine, and the Transformation of Sex in Modern China Howard Chiang

New York, NY: Columbia University Press, 2018. xvii + 219

Across various epochs of Chinese history, eunuchs held considerable political power and control over the state. During the late Qing, however, at a time when China came to be regarded as the 'Sick man of Asia' and as a 'castrated civilization', the figure of the eunuch became synonymous with ideas of backwardness, oppression and national shame. While many studies of Chinese eunuchs have tended to center on questions of their political life and institutional power, After Eunuchs, written by Howard Chiang, takes a very different approach.

After Eunuchs providing a fascinating and persuasive analysis of the demise of castration in the late nineteenth and early twentieth centuries as a pivotal turning point in the production of sexual knowledge in modern China. Tracing the genealogical relationship between eunuchs in Imperial China and a famous case of the "first" Chinese transsexual in 1950s Taiwan, After Eunuchs examines the ways in which the translations of Western sexological texts, concepts, and methodologies provided the essential historical conditions under which new ideas about sex, sexuality and the body as objects of empirical knowledge would emerge in China. Meticulously researched and drawing upon an impressive range of sources across medical science, popular press, and personal biographies, Chiang shows how Western biomedicine shaped and transformed sexual knowledge in China during the first half of the twentieth century, as well as how the rise of these new structures of knowledge and 
new regimes of conceptualization illuminate broader concerns about China's political and national sovereignty during this era.

Over the course of five convincingly argued chapters, Chiang identifies the visual realm, the subjectivity of human desire and the malleability of the body as the three key coordinates in an 'epistemic nexus' (13) around which new ideas about sex began to take shape during the Republican era. In Chapter One, 'China Castrated', he explores the historical production of knowledge about castration, revisiting the history of eunuchs through the prism of their bodily experiences. Chiang offers incisive analysis on the formation of a textual and visual archive by Western doctors, figures of the imperial court, and eunuchs themselves that documented the methods of castration in China and provides important reflections on how assumptions about masculinity, resulting from confusion over the nature and consequences of castration, have impacted the narration of the historical experience of eunuchs.

Chapter Two, 'Vital Visions', investigates how new visual techniques of medical representation made it possible for sex to become an object of empirical knowledge. Here, Chiang explores how Republican-era biologists and popular science writers translated the epistemological authority of natural science through the production of anatomical, morphological, and chromosomal images of sexual difference. He also provides a detailed account of the role of the image in the gradual spread of the western biological epistemology of sex from elite medical circles to vernacular popular culture.

Chapter Three, 'Deciphering Desire', examines the emergence of sexuality. Centering on the intellectual journeys of Zhang Jingsheng and Pan Guangdan, two key figures in Republican-era Chinese sexology, Chiang analyzes the lively and vibrant discussions about sexual desire that took place across scientific and popular literature, and how the concept of homosexuality emerged as a meaningful discursive point of referencing human difference and cultural identity in early twentieth century China. 
The next chapter, 'Mercurial Matter', describes how Chinese sexologists came to embrace the plausibility of sex transformation and the related discourses of 'sex change' that developed across mass circulation media from the 1920 s to the 1940 s. Taking as a case study the highly sensationalized media reportage of the story of Yao Jinping and his female-to-male transformation in mid 1930s Shanghai, Chiang shows how the 1940s represented a new era where people began to consider sex reassignment opportunities through the possibility of surgical intervention.

The final chapter focuses on the growing frequency of sex-change related discussions in Chinese-speaking communities in the immediate post-WWII era. Detailing the media characterizations of an intersex soldier in Tainan named Xie Jianshun and the publicity that followed her transition, Chiang analyzes how the mass circulation press introduced Xie's story to readers across Taiwan. In doing so, he considers shifting understandings of transsexuality, as well as the role of medical science and their evolving relation to the popular press in midtwentieth century Sinophone culture. Here, Chiang neatly locates these stories of corporeal variance within the convergence of culture and geopolitics in early Cold War Taiwan.

This book makes a rich and imaginative contribution to discussions about the psychobiological understandings of sex and sexuality that emerged in China in the nineteenth and twentieth centuries. By showing the significance of those decades between empire and communism as an important interlude in China's modern history, Chiang's work challenges the view that only after the economic reforms in the 1970s did China 'open up' to the global circulation of ideas regarding sex, sexuality and the body. Drawing attention to sexual knowledge as a significant element in the formulation of Chinese modernity, his book also provides an engaging and innovative analysis of the gradual displacement of colonial modernity by Sinophone articulations from the middle of the twentieth century onwards. After Eunuchs will be of great interest and importance to scholars working on the history of science and medicine, sex and sexuality, and Chinese modernity. 
Séagh Kehoe is postdoctoral research and teaching fellow at the Contemporary China Centre, University of Westminster 